\title{
The argument structure of adjectival participles revisited
}

\author{
Artemis Alexiadou, Berit Gehrke, Florian Schäfer
}

\section{Introduction}

One central question that has preoccupied the literature on adjectival passive participles has been to delineate and account for their properties in comparison to verbal passive participles, on the one hand, and the similarities and differences between adjectival passives and adjectives on the other (see, e.g., Wasow 1977, Levin and Rappaport 1986, Lazckó 2001, Emonds 2006). Kratzer's (2000) contribution substantiates the division of adjectival participles into two semantic subclasses in German, based on whether or not they can be modified by immer noch 'still'. Target state participles, which are compatible with immer noch, are argued to describe reversible, transitory states and to be derived from categoryless stems that have both an event and a target state argument (1a). Resultant state participles (borrowing a term from Parsons 1990), in turn, cannot combine with immer noch; Kratzer argues that these participles are derived from verbs and introduce states that hold forever after the event that brings them about (1b), formalized by employing a perfectivity operator.
a. Die Geißlein sind (immer noch)
versteckt.
TARGET STATE the goats are still
hidden
'The goats are still hidden.'
b. Das Theorem ist (*immer noch) bewiesen. the theorem is still proven
RESULTANT STATE intended: 'The theorem is still proven.'

She furthermore argues that both types of participles lack Voice, i.e. that the external argument is completely absent. Apparent evidence for this claim comes from the lack of control into purpose clauses (2a) (see also Baker et al. 1989) and the lack of the so-called disjoint reference effect (3a) in adjectival participles, i.e. the availability of a reflexive reading, as opposed to verbal participles $(2 \mathrm{~b}, 3 \mathrm{~b})$ (see also Kratzer 1994). ${ }^{1}$

(2) a. *Der Reifen war aufgepumpt, um die Fahrt fortzusetzen. the tire was inflated in order the journey to continue intended: 'The tire was inflated in order to continue the journey.'
b. Der Reifen wurde aufgepumpt, um die Fahrt fortzusetzen. the tire became inflated in order the journey to continue 'The tire was (being) inflated in order to continue the journey.'

(3) a. Das Kind war schlampig gekämmt. the child was slopp(il)y combed

\footnotetext{
${ }^{1}$ Note that German makes a morphological distinction between adjectival and verbal passives, in that adjectival (past) participles combine with an inflected form of sein 'to be', whereas verbal (past) participles combine with an inflected form of werden 'to become'. If combination with (the copula) sein is the defining characteristics for a participle to be adjectival, as is commonly assumed (disregarding the combination of the auxiliary sein with participles derived from unaccusative predicates in perfect constructions; but see also Gese et al. 2011), then both types of participles are adjectival, and we follow this common assumption. Kratzer's overall conclusions, however, seem to suggest that she views both types of participles as stativized, but resultant state participial constructions as verbal, rather than adjectival.
} 
'The child was combed in a sloppy manner.'

(i) Someone (else) (has) combed the child.

DISJOINT INTERPRETATION

(ii) The child (has) combed him/herself.

REFLEXIVE INTERPRETATION

b. Das Kind wurde schlampig gekämmt.

the child became slopp(il)y combed

'The child was (being) combed in a sloppy manner.'

(i) = Someone (else) (has) combed the child.

DISJOINT INTERPRETATION

(ii) NOT: The child (has) combed him/herself.

REFLEXIVE INTERPRETATION

Alexiadou \& Anagnostopoulou (2008), building on Anagnostopoulou (2003), argue that this semantic difference between the two types of adjectival (or stativized; $\mathrm{cf}$. fn. 1) participles is a direct reflection of a structural difference, In particular, they propose that Greek stative participles in -tos, which lack event implication, are root-derived (4a). The term 'stative' here is adopted from Embick (2004) who proposes a structural distinction between root-derived stative participles and verb-derived resultative ones. ${ }^{2}$ Furthermore, (English, German and Greek -menos) target state participles are argued to be directly derived from vPs (4b), whereas only Greek resultant state (-menos) participles can involve a Voice layer on top (4c); a similar argument in favor of the presence of Voice in participles has been made for Hebrew participles derived from the causative template (Doron to appear). ${ }^{3}$
a. [Asp [Root]]
b. $[$ Asp [vP [Root $]]$
c. $[$ Asp [VoiceP [vP [Root]]]]
(English, German, Greek -tos stative participles) (English, German, Greek -menos TS participles) (Greek -menos RS participles, Hebrew causative template)

Embick (2004) presented the following argument for the absence of a v layer in purely stative participles (i.e. not necessarily target state participles). Like the adjective in (5a), the participle in (5b) expresses a situation in which the door never participated in a change-ofstate event.

(5) a. This door was built open/*opened.

b. This door was built closed.

Based on data like these and others, Embick concludes that participles that can appear in the complement of verbs like build involve a root-derivation.

Recently, this picture has been challenged in various ways. Anagnostopoulou \& Samioti (to appear) argue that in Greek even stative -tos participles could involve a verbal layer (vP). They also argue that certain -tos participles expressing possibility/ability can even contain VoiceP (based on Samioti to appear). Furthermore, McIntyre (2013) and Bruening (to appear) show that English adjectival participles can license $b y$-phrases and conclude from this that

\footnotetext{
${ }^{2}$ Since Kratzer (2000), Anagnostopoulou (2003) and Embick (2004), many authors have proposed similar structural differences for various languages, under either or both pairs of labels and with some variation as to the precise nature of the structural differences (see, e.g., Lundquist 2008, Sleeman 2011). We would like to point out, however, that these two different systems of classification are not in a one to one mapping relationship, as we will make more precise in section 2. In particular, Kratzer's target state participles are not necessarily stative in Embick's system, and neither are Embick's resultative participles necessarily equated with resultant state participles (see also the discussion in Alexiadou et al. to appear, which clarifies this terminological confusion). Many thanks to Elena Anagnostopoulou for further discussion on this point.

${ }^{3}$ Kordoni (2002) also provides empirical support for the presence of an external argument in -menos participles and spells out an LFG account, according to which a verbal participle with the complete argument structure of the underlying verb is converted into an adjective.
} 
they must, therefore, involve a Voice layer just as verbal participles.

In this paper, we propose that adjectival passives can involve more verbal functional structure than assumed even in German and English. In Section 2, we provide morphological evidence that some adjectival target state participles must involve a verbal eventive layer, and that some, in addition, involve Voice, which provides further evidence that, at least in some cases, verbal and adjectival passives can be structurally quite similar. ${ }^{4}$ In Section 3 we provide further evidence for the presence of Voice from the availability of event-related modifiers with adjectival participles, such as $b y$-phrases; we also discuss that there are some restrictions on these in English and German, but not in Greek. In Section 4, we propose a structural account according to which adjectival participles can be of different size and involve the adjectivization of a root, a verbalized root (involving an additional vP layer; as proposed by Anagnostopoulou 2003, Embick 2004), as well as a the adjectivization of a VoiceP (located above vP; as proposed by McIntyre 2013, Bruening to appear) (in analogy to what Anagnostopoulou 2003 proposed for Greek). We suggest that the restricted availability of event-related modifiers in English and German can be explained semantically despite the presence of Voice; in particular, we follow Gehrke (2011, and subsequent work) in assuming that the event involved in adjectival passives remains in the kind domain so that event modification is restricted to kind modification. In Section 5, we follow Alexiadou et al. (to appear) and propose that differences between Greek and German/English adjectival passives in the availability of such modifiers follow naturally if we assume that Greek adjectival participles can involve an additional Perfect operator (building on Kratzer 2000), which is responsible for the event getting instantiated. We hypothesize that the Greek resultant state participle is ambiguous between an adjectival passive and the perfect of an eventive passive, as in this language this participle formation makes use of the same building blocks as a verbal passive. Finally, Section 6 concludes. A general conclusion that we will draw is that unlike often (explicitly or implicitly) assumed, Embick's division of the class of adjectival participles is not the same as Kratzer's division; rather, Embick's resultatives subsume Kratzer's phrasal target states as well as her resultant states.

\section{Morphological evidence for verbal structure}

In this section we provide morphological evidence for postulating additional verbal functional structure in adjectival participles. The existence of verbalizing morphology inside some participles suggests that these participles contain an eventive $\mathrm{v}$ layer, whereas transitivizing morphology points to the existence of a Voice layer inside such participles.

\subsection{Target state participles can involve overt verbalizing heads.}

Alexiadou \& Anagnostopoulou (2008) proposed that target state participles, which include the implication of an event, necessarily include a vP layer across languages. However, they did not present any detailed evidence from morphology in favor of this view as far as English and German are concerned. In this section, we make a stronger case that target state participles contain such a layer in German and English.

In English and German, many verbs are derived from some non-verbal source (category-neutral Roots in our terminology) by the addition of verbalizing affixes. In this paper, we take a Distributed Morphology (DM) approach and take verbalizing affixes to be the spell-out of a v-head, assuming that their presence is clearly related to the verbal/eventive nature of the verbs (see in particular Embick 2004). Harley (2011), for example, argues for

\footnotetext{
${ }^{4}$ Our claim is not that ALL adjectival participles involve a verbal eventive layer; sometimes, adjectival participles lack any eventive verbal layers, as suggested by (5) for which we assume the structure in (4a).
} 
English that affixes like -ify, -ate and -ize are specific verbalizing morphology. In (6) we see that participial morphology can attach to these verbalizers to form a verbal or an adjectival participle. This suggests that the verbalizing head is still present in the participle, and that the participle morphology does not attach directly to the root.

$\begin{array}{llllll}\text { Root: } & \sqrt{ } \text { COLON } & \sqrt{ } \text { MOBIL } & \sqrt{ } \text { DICT } & \sqrt{ } \text { HTML } & \sqrt{ } \text { SATIS } \\ \text { Root + v: } & \text { colon-ize } & \text { mobil-ize } & \text { dict-ate } & \text { html-ify } & \text { satis-fy } \\ \text { participle: } & \text { colon-iz-ed } & \text { mobil-iz-ed } & \text { dict-at-ed } & \text { html-ifi-ed } & \text { satis-fi-ed }\end{array}$

The logic of this argumentation predicts that adjectival participles of the form in (6) involving verbalizing suffixes should not be compatible with Embick's context in (5), as they are not derived from roots but involve an eventive layer. While at first sight this prediction seems to be borne out (7a), we have not been able to find English minimal pairs (adjective vs. participle), which could support this point, i.e. where not only the participle is ungrammatical but the adjective is conceptually acceptable as the complement of built; cf. (7a, b) vs. (5a, b).

(7) a. *The rail-trail was built electrified.

b. *The rail-trail was built electric.

In German, we face the same problem with this particular example; we find both sentences in (8) unacceptable.

(8) a. *Die Straßenbeleuchtung wurde elektrisch gebaut. The road lighting became electric built intended: 'The road lighting was built electric.'

b. *Die Straßenbeleuchtung wurde elektrifiziert gebaut. The road lighting became electrified built intended: 'The road lighting was built electrified.'

However, with another example, which displays the same kind of contrast, in this case one between the adjective stabil 'stable' and the participle stabilisiert 'stabilized', our prediction seems to be testable; in our judgements (9a) with an adjective is an acceptable continuation of the given context while (9b) with the adjectival participle involving a verbalizer is strongly degraded:

(9) Es gab ein Haus, das war so instabil, dass es zusammengebrochen ist. it gave a house that was so unstable that it collapsed is 'There was a house, that was so unstable that it collapsed.'

a. Das nächste Haus haben sie dann aber stabil errichtet/gebaut. the next house have they then but stable constructed/built 'However, the next house they built more stable.'

b. *Das nächste Haus haben sie dann aber stabilisiert errichtet/gebaut. the next house have they then but stabilized constructed/built intended: 'However, the next house they built more stabilized.'

To clarify this issue we resorted to other verbs that should behave like build in not allowing resultative participles as their complements, for example konzipieren 'to design'. Our judgments, then, suggest the following contrast:

(10) a. Die Straßenbeleuchtung wurde von Anfang an elektrisch konzipiert. 
the road lighting became from beginning on electric designed 'From the start, the road lighting had been designed electric.'

b. ??Die Straßenbeleuchtung wurde von Anfang an elektrifiziert konzipiert. the road lighting became from beginning on electrified designed intended: 'From the start, the road lighting had been designed electrified.'

A Google search for German supports this contrast at least by trend, as illustrated in (11). ${ }^{5}$

(11) "elektrisch gebaut" ('built electric')
"elektrifiziert gebaut" ('built electrified')
"elektrisch konzipiert" ('designed electric')
"elektrizifiert konzipiert" ('designed electrified') about 100 hits

8 hits

16 hits

0 hits (1 irrelevant hit)

Embick (2004) mentions a further suffix -en, which could be added to the three suffixes discussed above (-ate, -ify, -ize) as another verbalizing morpheme. Embick (2004: 357 ex. (7)) provides an example with an -en participle paired with a proper adjective, which shows that the contrast we are after, is also found in English:

(12) a. This new ruler was built long.

b. *This new ruler was built lengthened.

Finally, an anonymous reviewer pointed out the following contrast:

(13) a. The house was built solid.

b. *The house was build solidified.

Hence, the prediction seems to be borne out: These participles have an event implication due to the presence of verbalizing morphology inside of them and they are not derived directly from the root. Thus, they behave on a par with Embick's resultative participles. ${ }^{6}$

At this point we note that Embick's resultative participles cannot be identified with Kratzer's resultant state participles (see fn. 2). In particular, a number of participles involving overt v-layers (and thus behaving like Embick's resultative participles) instead pattern with Kratzer's target state participles in being compatible with still (14).

(14) a. The boss is still satisfied.

b. The patient is still hospitalized.

\footnotetext{
${ }^{5}$ An anonymous reviewer pointed out that strings like those in (11), e.g. elektrisch gebaut 'built electric', can also be read not as involving an adjective as a secondary predicate (e.g. electric) but as involving an adverb (e.g. electrically), given that German does not morphologically distinguish between adjectives (in predicative position) and adverbs. We checked our Google search data again; it turned out that this misleading interpretation is basically never relevant.

${ }^{6}$ The same reviewer pointed out a possible counterexample, in which an adjectival participle with apparent verbalizing morphology is allowed as complement of the verb to build, which (s)he came across on a Google search:
}

(i) a. The house is built long and narrow.

b. The terrace is built elongated.

The point raised concerning lengthened vs. elongated (i.e. the former seems to be blocked by long, the latter not) is interesting. We suspect that elongate, which seems to involve the prefix $e$-, might not be derived in present day English but involve a root elongate. More concretely, we suggest that it is a Latinate root derived from the participle elongatus. 
c. The city is still electrified.

d. The country is still colonized.

(15) shows that the same holds for German.

(15) a. Der Patient ist immer noch hospitalisiert.

The patient is still hospitalized

'The patient is still hospitalized.'

b. Die Armee ist immer noch mobilisiert.

the army is still mobilized

'the army is still mobilized.'

c. Das Wassergeschäft ist immer noch privatisiert.

The water-business is still privatized

'The water-business is still privatized.'

d. Das Land ist immer noch kolonialisiert.

The country is still colonized

'The country is still colonized.'

This suggests that at least some participles that behave like target state participles are not derived from the root but contain an additional verbalizing layer, contra Kratzer (2000) (see also Alexiadou \& Anagnostopoulou 2008, and Anagnostopoulou's 2003 discussion of phrasal target state participles).

In the following section, we will show that some participles that behave like Kratzer's target state participles involve transitivizing morphology, which suggests that they contain an additional Voice layer on top of $\mathrm{v}$, as argued for by Doron (to appear), based on similar facts from Hebrew.

\subsection{Target state participles can involve transitivizing morphology}

German has a few verbs that mark the causative alternation with a stem alternation (cp. English rise vs. raise, lie vs. lay). ${ }^{7}$ With the German counterpart of sink, for example, the transitive and the passive form are weakly inflected and use the fixed stem vowel $e(16 \mathrm{a}, \mathrm{b})$, while the anticausative form is strongly inflected and uses the Ablaut stem vowels $i$ and $u$ (as well as $a$ in the past) (16c, d).

(16) a. Hans versenkt /*versinkt das Schiff.

(causative active) John sinks TRANS $_{\text {I }} /$ sinks $_{\text {INTRANS }}$ the ship

b. Das Schiff wurde (von der Marine) versenkt /*versunken. (causative passive) the ship was (by the marine) sunken $_{\text {TRANS }} /$ sunken $_{\text {INTRANS }}$

c. Das Schiff versinkt /*versenkt.

(anticausative) the ship sinks INTRANS $_{\text {I }}$ sinks TRANS $_{\text {S }}$

\footnotetext{
${ }^{7}$ Other verbs with this property are given in (i-iv). Scandinavian languages, e.g. Icelandic (Maling \& Zaenen 1990, Sigurðsson 1989) or Norwegian (Peter Svenonius p.c.) have a bigger number of relevant verbs.

(i) a. Er hat den Baum gefällt. he has the tree felled TRANS $_{\text {Tand }}$

b. Der Baum ist gefallen.

the tree is fallen INTRANS $_{\text {s }}$

(ii) a. Er hat das Bild an die Wand gehängt. b. He has the picture on the wall hung TRANS $_{\text {Th }}$

(iii) a. Er hat das Kind erschreckt. he has the child frightened $\mathrm{T}_{\text {TRANS }}$

(iv) a. Er hat das Kind aufgeweckt. he has the child waked TRANS $_{\text {S }}$
} 
d. Das Schiff ist versunken /*versenkt.

(anticausative; perfect tense)

the ship is sunken $_{\text {INTRANS }} /$ sunken $_{\text {TRANS }}$

Within a DM perspective, such morphological shifts must be related to the presence vs. absence of higher verbal structure, i.e. verbal structure on top of the first verbalizer/eventivizer v. In principle, two types of verbal heads present in causatives but not in anticausatives could be relevant for this morphological shift, either a further eventive vhead or a Voice head introducing an external argument (cf. Embick 2010). ${ }^{8}$ However, a number of authors have argued (mainly on the basis of adverbs interacting semantically with events) that causatives do not differ from anticausatives in event complexity, i.e. there is no empirical motivation that causatives involve more eventive verbal layers than anticausatives (e.g. von Stechow 1996, Pylkkänen 2008) (see Martin \& Schäfer to appear for further references and discussion). Therefore, we follow Kratzer (2005), Alexiadou et al. (2006, to appear) and Schäfer (2012), and take both causatives and anticausatives to be bi-eventive (in the sense that they involve two eventualities, one verbal event $v$ and a Result State), so that the former differ from the latter only in the presence of a Voice layer (Kratzer 1996) introducing an external argument, as illustrated in (17).
a. [Voice [ v [ STATE ]]]
(causative)
b. $\quad[\mathrm{v}[\mathrm{STATE}]]$
(anticausative)

Under this conception, the presence vs. absence of the Voice layer triggers the stem alternation in (16). Specifically, we analyze ver-sinken/ver-senken as follows: the prefix verintroduces the result state, sink modifies v, and senk is the Spell Out of sink in the context of Voice (active or passive).

Turning back to adjectival passives, we crucially observe that not only the anticausative version of German sink can form an adjectival participle (18a), but also the causative form can (18b).

(18) a. Das Schiff ist schon lange versunken. the ship is already long sunken INTRANS $_{\text {S }}$

b. Das Schiff ist schon lange versenkt. the ship is already long sunken TRANS

This suggests that Voice can be present in adjectival passives, contra traditional assumptions about the general absence of Voice in adjectival participles in German. The verbal input to such participles is thus even bigger than what Embick suggested for resultative participles.

This leads us to the second piece of evidence that Kratzer's distinction between target state and resultant state participles does not match Embick's distinction. In particular, we observe that the above adjectival participle which, in our analysis, must involve Voice, behaves like target state participles. While das Schiff versenken does not really form a target state participle, as the still-modification test is only possible if the state is in principle reversible

\footnotetext{
${ }^{8}$ That is, anticausatives would involve one eventive layer (v-BECOME) while causatives would involve an additional verbal layer on top (v-CAUSE) as well as a Voice Projection as in (i).

(i) a. [Voice $[\mathrm{v}$-CAUSE $[\mathrm{v}$-BECOME $[$ STATE $]]]]$ (causative)

b. $\quad[\mathrm{v}$-BECOME [ STATE $]]$ (anticausative)

Under such a decomposition one could argue that adjectival participles of causatives do not involve Voice but vCAUSE which triggers the stem alternation. However, as mentioned in the main text, there are no empirical arguments for an additional verbal layer in causatives.
} 
(19a), examples with reversible states, such as (19b), readily allow for still-modification with both, their anticausative but also their causative, transitive basis.

(19) a. ??Das Schiff ist immer noch versenkt.

$$
\text { the ship is still sunken }{ }_{\text {TRANS }}
$$

b. Die Münze ist immer noch im Aquarium versenkt / versunken.

the coin is still in.the aquarium sunken $_{\text {TRANS }} /$ sunken $_{\text {INTRANS }}$

In sum, the analysis of morphological effects within the framework of DM suggests that target state participles can contain verbal structure and are not equivalent to Embick's stative participles (which are necessarily derived from the root). Morphologically, we can identify two verbal layers, an eventive verbalizer (little v) and a transitivizer (Voice). We have also suggested that the presence of verbalizing morphology has semantic effects: at least the predictions are clear; they should always trigger an event implication and purely stative/adjectival readings/contexts should be out.

In the following section, we will explore the question whether the presence of transitivizing morphology implies the presence of an external argument.

\section{Is the external argument present in the structure of adjectival participles?}

In the previous section, we have seen that the verbs undergoing the causative alternation with a specific form of morphological marking on the stem form two adjectival participles directly related to this morphological marking. Commonly, with minimal pairs related to these verbs, other than those based on adjectival participles, this morphology reflects semantic (in)transitivity (cf. (16a-d)), which in turn is determined syntactically by the presence/absence of active or passive Voice. In (20), we see that this transitive/intransitive opposition is also found with adjectival participles, at least at an intuitive level, since there is a clear difference in interpretation. In particular, the necessarily adjectival passive based on the causative versenkt implies an external argument (20a), while (verbal or adjectival) participles based on anticausative versunken lack such an implication (20b).
a. Hurra, das Schiff ist \{endlich / seit $14 \mathrm{Uhr}$ \} versenkt. hooray, the ship is finally since 14 o'clock sunken TRANS $=>$ job-is-done reading (cf. Kratzer 2000)
b. Hurra, das Schiff ist \{endlich / seit $14 \mathrm{Uhr}$ \} versunken. hooray, the ship is finally since 14 o'clock sunken INTRANS $_{\text {s }}$ $=>$ no obvious job-is-done reading though compatible with such a scenario

Negation of a causative event with these participles points into the same direction, since it is possible with the adjectival participle based on the anticausative (21a) but unacceptable with the adjectival passive based on the causative version (21b).

(21) a. Die Münze ist schon lange versunken, aber keiner hat sie je versenkt.

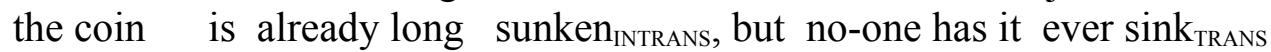

b. Die Münze ist schon lange versenkt, *aber keiner hat sie je versenkt. the coin is already long sunken $n_{\text {TRANS, }}$ but no-one has it ever sink $k_{\text {TRANS }}$

However, we also know that the adjectival participle of a transitive verb like kill implies an external argument at some level. For example, the sentence in (22) is not compatible with a situation where the president simply died from old age. 
(22) Der Präsident ist getötet.

the president is killed

'The president it killed.'

The implication of an external argument here is not morphologically conditioned, though, since transitivizing morphology is absent in such examples and one could assume that the notion of an external argument arises only due to conceptual knowledge about killing events (e.g. Alexiadou et al. 2006). This, in turn, opens up the possibility that the implication of an external argument in adjectival passives in general might be conceptually and not structurally conditioned (see also the discussion in Bhatt \& Pancheva 2006).

However, we find such a move problematic. In particular there are several tests that are intended to diagnose the presence of an implicit external argument at a syntactic level, most prominently control into purpose clauses and the disjoint reference effect (see (2) and (3)), but also the presence of $b y$-phrases. As we have noted above, the traditional view is that these tests give different results in verbal and in adjectival passives (Baker et al. 1989, Kratzer 1994, 2000, among others), suggesting that the latter lack Voice. Greek has been noted to be an exception for many of these tests (Kordoni 2002, Anagnostopoulou 2003, Alexiadou \& Anagnostopoulou 2008, Anagnostopoulou \& Samioti to appear). The received view for German is that adjectival passives contrast with verbal passives in their highly restricted availability of $b y$-phrases and event-related adverbial modification. For English, it is commonly assumed that $b y$-phrases are unavailable altogether, and if counter-examples to this assumption are found, they are commonly explained away (see, e.g., Levin \& Rappaport 1986). This standard view translates into a theoretical picture, according to which Greek adjectival passives have Voice, whereas English and German adjectival passives lack Voice. In the following, we will show that these standard assumptions about English and German adjectival participles cannot be maintained.

\subsection{By-phrases and event-related modification in adjectival passives}

The standard claim for English is that adjectival passives are incompatible with $b y$-phrases, and to our knowledge there is little discussion on other event-related modifiers in English adjectival passives. The generality of this claim has been challenged recently, also for other languages, for which it has been shown that event-related modifiers are available (yet more restricted in the languages in A. as opposed to B.):

A. German (e.g., Rapp 1996, Maienborn 2007a, Gehrke 2011)

English (McIntyre 2013, Bruening to appear)

Spanish (Gehrke \& Sánchez-Marco this volume)

Hebrew (Meltzer-Asscher 2011)

B. Greek (e.g., Anagnostopoulou 2003, Alexiadou \& Anagnostopoulou 2008)

Hebrew (Doron to appear, for the causative template)

We will first turn to by-phrases. Greek (23a) but not German (23b,c) or English (23d) participles allow for all kinds of $b y$-phrases.

a. To psari itan tiganismeno apo tin Maria.

by the Mary

(Anagnostopoulou 2003)

'The fish was fried by Mary.' 
b. Der Fisch war (*von Maria) gebraten.

(Anagnostopoulou 2003)

the fish was by Mary fried

intended: 'The fish was fried by Mary.'

c. Der Mülleimer ist (*von meiner Nichte) geleert.

the rubbish bin is by my niece emptied

intended: 'The rubbish bin is by my niece emptied.'

d. The door seemed $\{$ broken/opened/painted (*by Mary).

(Rapp 1996: 246)

(McIntyre 2013)

Some by-phrases, however, are acceptable also in German (and sometimes they get better in a particular context, see Rapp 1997, Maienborn 2007a, among others), as illustrated in (24).

(24) Die Zeichnung ist von einem Kind angefertigt.

the drawing is by a child produced

'The drawing is produced by a child.'

(Rapp 1997: 192)

Rapp (1997) suggests that only those by-phrases are possible that are characteristic for the result state, but she does not spell out what exactly this means, neither in semantic nor in syntactic terms. Meltzer-Asscher (2011) maintains that adjectival passives only make available a state (as all adjectives do) and that the event and an external argument are completely absent; she proposes that event-related modifiers modify the state directly and result in the reconstruction of an event related to the state by a meaning postulate (MeltzerAsscher). One could wonder, then, whether the restrictions on event-related modification follow from general restrictions on state modification, as described in Maienborn (2007b). However, Gehrke (2013) points out that the restrictions on event-related modification do not match the restrictions on state modification, and that an account that assumes an event (i.e. verbal structure) inside deverbal adjectives is to be preferred. Anagnostopoulou (2003), in turn, makes a structural distinction between high agent-oriented (Voice-related) and low result-oriented manner adverbs and argues that German adjectival passives only allow for the latter. In principle, then we could extend this account to by-phrases and make a distinction between Voice-related by-phrases that are disallowed with adjectival passives and low resultrelated ones that are allowed.

However, there are several reasons not to follow this route. For one thing, many byphrases that are acceptable with German adjectival passives, such as the one in (24), are clearly event- rather than state-related and name an agent of the underlying event. Furthermore, changing the determiner of the complement of the $b y$-phrase in (24) renders this example ungrammatical, as shown in (24').

(24') *Die Zeichnung ist von dem Kind angefertigt. the drawing is by the child produced

Arguing that the by-phrase in (24') is agent-related and in need of licensing by Voice whereas the one in (24) is result-related seems rather stipulative. Gehrke (2013, to appear) shows instead that the generalization for event-related by-phrases in combination with German adjectival passives is that these are acceptable with nominal complements that can receive some kind of generic interpretation (mostly indefinite or bare nominals), but unacceptable with complements that refer to a particular referent in the discourse (mostly definite NPs, including personal pronouns and proper names). ${ }^{9}$ She proposes that the restrictions on event-

\footnotetext{
${ }^{9}$ In addition, there are state-related $b y$-phrases that appear with adjectival participles derived from stative predicates, e.g. von der Musik beeindruckt 'impressed by the music'. Such by-phrases do not display the restrictions outlined above for event-related by-phrases, and also differ from the latter in terms of prosody,
} 
related modification with adjectival passives follow from the idea that the underlying event does not get instantiated but remains in the kind domain. Event-related modification, then, is only possible if it can modify an event kind, hence the preference for $b y$-phrases with a generic flavour. We will discuss this idea in more detail in Section 4.

McIntyre (2013) and Bruening (to appear) show that by-phrases can appear with adjectival passives in English as well and provide examples like the ones in (25).

(25) a. The dictator remained unsupported/underestimated by the warlords.

b. Former investigator says he remains disturbed by what he saw at baby murder scene.

c. No longer does Tim Thomas appear trained by Tim Hortons.

d. There are others who I would call saints more than theologians since they seem taught by God more than by men.

e. Once one monkey discovered a new food-washing method, very soon the whole tribe used the method, untaught by the original simian.

f. Steve Jobs' birthday doesn't go unnoticed by spammers.

A similar picture arises when we look at instruments, i.e. prepositional phrases headed by with. Greek participles allow for all kinds of instruments (26a), whereas this is not the case in German (26b).

(26) a. Ta malia tis basilisas ine htenismena me xrisi xtena. (Anagnostopoulou 2003) The hair the queen.GEN are combed with golden comb 'The hair of the queen is combed with a golden comb.'

b. Ihre Haare sind (*mit einem goldnen Kamm) gekämmt. her hair are with a golden comb combed

c. Der Mülleimer ist $(*$ mit der Heugabel) geleert. the rubbish bin is with the hayfork emptied

(Rapp 1996: 257)

(Rapp 1996: 246)

However, as in the case of $b y$-phrases, some instruments are acceptable also in German adjectival participles (with similar semantic restrictions as discussed in the context of byphrases), as illustrated in (27).

(27) Der Brief war mit roter Tinte/mit einem Bleistift geschrieben.

(Rapp 1997:192)

the letter was with red ink/ with a pencil written

A similar picture emerges for English; we cite data from McIntyre (2013) and Bruening (to appear) in (28). ${ }^{10}$

(28) a. The radioactive nucleotides are so small that they remain unseen, even with the most powerful microscope.

b. Our Lord makes the DNA, the tiniest information bank of the world which is unseen

availability of word order variation, and other points (see Rapp 1997, Schlücker 2005, Gehrke 2013 for discussion of the German data) (see also McIntyre 2013, who labels such participles in English situation-inprogress participles). In the remainder of this paper, we will primarily be concerned with event-related byphrases.

${ }^{10}$ An anonymous reviewer pointed out that the examples in (28) are only acceptable with even. We agree that this is true for negated adjectival participles, which must introduce instruments with even, whereas un-negated ones do not need even (see Alexiadou et al. to appear for further discussion). This effect, however, is orthogonal to our point made in this section. As one can see in (27) the German data do not need 'even' as they do not involve a negated participle. The English data in (28), in turn, involve negated participles to ensure that we are dealing with an adjectival participle. 
even with the naked eye, ...

c. ... the very earliest stages of an arteriosclerotic plaque, which remains

undiscovered even with the most up to date clinical diagnostics.

Finally, only Greek freely allows all kinds of event-related adverbials (29), whereas there are severe restrictions in German (30).

(29) a. To thisavrofilakio itan prosektika anigmeno.

(Anagnostopoulou 2003)

the safe was cautiously opened

'The safe was cautiously opened.'

b. To pc itan diorthomeno prin tris meres.

the pc was repaired three days ago

'The pc was repaired three days ago.'

c. To pedi itan htenismeno sto banio.

the child was combed in the bathroom

'The child was combed in the bathroom.'

(30) a. Der Mülleimer ist *langsam / *genüsslich geleert. the waste-bin is slowly / enjoyably emptied

(Rapp 1996:246)

b. *Der Computer ist vor drei Tagen repariert.

the computer is before three days repaired

(von Stechow 1998)

intended: 'The computer is repaired three days ago.'

c. *Das Kind war im Badezimmer gekämmt.

the child was in.the bathroom combed

(Gehrke 2012)

intended: 'The child was combed in the bathroom.'

Again, some such adverbs are acceptable, as illustrated for German in (31).

(31) Die Haare waren schlampig gekämmt / geschnitten.

(Kratzer 2000)

the hairs were slopp(il)y combed / cut

'The hair was sloppily combed / cut.'

To our knowledge, the literature on English does not really discuss data like these, but the following examples suggest that English behaves like German in this respect. ${ }^{11}$

(32) a. *The waste-bin is emptied slowly / with pleasure.

b. *The computer is repaired three days ago.

c. *The child is combed in the bathroom.

d. Her hair is sloppily combed / cut.

In sum, event-related by-phrases, instruments and adverbs can be found in both verbal and adjectival passives. While in English and German these are more restricted in adjectival participles than in verbal passive participles, Greek adjectival participles allow such modifiers quite unrestrictedly. These facts led Anagnostopoulou (2003) to argue that some Greek adjectival participles (resultant state participles ending in -menos) involve a Voice projection, whereas German adjectival passives never do. However, positing that German adjectival passives generally lack Voice is immediately called into question by the Voice-related morphology we discussed in Section 2. Hence, we will not pursue this kind of approach.

\footnotetext{
${ }^{11}$ The starred examples are out only under the adjectival passive reading, not under the verbal passive reading.
} 
Instead, in Section 4, we will combine the semantic perspective provided by Gehrke (2011, and subsequent work), according to which restrictions on event-related modification follow from general restrictions on event kind modification, with the syntactic perspective presented for English in McIntyre (2013) and Bruening (to appear) that Voice is present also in adjectival passives.

In the following, we will show that the alleged absence of control into purpose clauses as well as the absence of a disjoint reference effect, both of which have been taken as syntactic key arguments for the absence of an external argument in adjectival passives, do not hold true in all cases of adjectival passives and further call into question the alleged absence of an external arguments from adjectival passives.

\subsection{Control and disjoint reference effects in adjectival passives}

As mentioned in the introduction, the possibility of control into purpose clauses has been taken as a central piece of evidence in favour of a syntactically present (or syntactically active) external argument in verbal passives. The received view holds that Greek but not German/English adjectival passive constructions allow control into purpose clauses, as illustrated by the contrast between (33a), on the one hand, and (33b) and (33c) on the other. This has led to the general assumption that external arguments are present in Greek adjectival passives but absent from German and English ones.

a. Aftos o pinakas ine zografismenos apo mia This the painting is painted by a omadha aktiviston gia na sokarun tus anthropus. (Anagnostopoulou 2003) group activists-GEN for to shock-pl the people 'This painting is painted by a group of activists in order to shock the people.'

b. Das Kind ist schlampig gekämmt, (*um die Großmutter zu schockieren). (An. 2003) the child is slopp(il)y combed in-order the grandmother to shock intended: 'The child is sloppily combed in order to shock the grandmother.'

c. The idea seemed widely publicised (??in order to discredit him). (McIntyre 2013)

However, it can be shown that at least in some cases both English and German participles allow Control into purpose clauses. McIntyre (2013) provides the following examples from English (the choice of remain is to ensure that we are dealing with adjectival participles).

(34) a. The ... bags remained closed in order to keep the modified atmosphere intact.

b. Use of the name Blohm + Voss remained prohibited, in order to ... spare the world the shock that ships were being built there again.

c. The investigation launched by the prosecution remained limited in order to protect the police.

We also found plenty of Control examples for German on Google, such as the ones in (35); recall that the choice of the copula be ensures that we are dealing with adjectival participles.

(35) a. Nachdem die Manschette aufgepumpt ist, um den Blutstrom in der Arterie after the cuff up-pumped is in-order the blood-stream in the artery zu blockieren, beginnt die Entlastung der Manschette.

to block begins the release the.GEN cuff

'After the cuff is pumped up in order to block the blood stream, begins the release of the cuff.' 
b. Wichtig ist, dass die Fronttube bei viel Wind gut aufgepumpt ist, important it that the front tube at much wind well up-pumped is um die Form optimal zu halten.

in-order the form optimally to keep

'It is important that, in the case of strong wind, the front tube is pumped up well in order to keep the form optimal.'

c. Alle anderen Bereiche sind versteckt, um den Mitgliedern maximale Sicherheit all other areas are hidden in-order the members maximal security vor neugierigen Blicken von außerhalb zu garantieren.

from curious looks from exterior to guarantee

'All other areas are hidden in order to guarantee all members maximal security.'

d. Die Partition ist versteckt, um ein versehentliches Löschen der Dateien the partition is hidden in-order an unintended erasing the.GEN data zu verhindern.

to prevent

'The partition is hidden in order to avoid that it gets deleted by mistake.'

However, the relevance of control data as a diagnostics for an implicit external argument is often rejected. In this context, William's (1985) example in (36) is typically cited, where a purpose clause can show up with a genuine adjective, which clearly lacks an external argument on any account.

(36) Grass is green in order to promote photosynthesis.

While we agree that purpose clauses can occur in the absence of a structurally represented implicit argument, this is possible only in a very restricted contextual setting. Since this restriction does not hold for adjectival participles, we think that, nevertheless, the data in (34)(35) are indicative for the presence of an implicit external argument in adjectival participles. In particular, it is well known that examples like (36) work in 'director-contexts', in which a powerful controller (a director, God, nature, or the like) is the subject of the purpose clause, as in $(37 \mathrm{a}, \mathrm{b}){ }^{12}$ To our knowledge, adjectives cannot license purpose clauses outside of such contexts; otherwise we would find examples like $(37 \mathrm{c}, \mathrm{d})$ good.

(37) a. The cat chosen is very big in order $\mathrm{PRO}_{\text {director }}$ to make it visible to the audience.

b. Peter $r_{i}$ was fast in order $\mathrm{PRO}_{\mathrm{i} / \text { director }}$ to impress the audience.

c. $\mathrm{My}_{\mathrm{j}}$ cat is big \#in order $\mathrm{PRO}_{\mathrm{j} / \mathrm{k}}$ to impress $\mathrm{my}_{\mathrm{j}}$ mother.

d. $\mathrm{I}_{\mathrm{j}}$ bought a new car. It is very big \#in order $\mathrm{PRO}_{\mathrm{j}}$ to impress my girl-friend.

In the above Control examples with adjectival passives, in contrast, we want to maintain that it is indeed the understood subject of the event associated with the adjectival passive, which controls PRO, not some contextually given director. Consider the contrast in (38), which shows that purpose clauses (whose subject is not controlled by God / a director) are possible (albeit slightly degraded) only with adjectival passives (38b), but not with adjectives (38a).

(38) a. Die Heizung ist ganz warm, *um einen gemütlichen Abend zu haben. the heating is very warm in-order a nice evening to have intended: 'The heating is very warm in order to have a nice evening.'

\footnotetext{
${ }^{12}$ We find the same with unaccusatives:

(i) The actor died/fell to shock the audience.
} 
b. Die Heizung ist (auf) ganz warm gestellt, ?um einen gemütlichen Abend zu haben. the heating is on very warm put in-order a nice evening to have 'The heating is put on very warm in order to have a nice evening.'

We conclude from data like these that purpose clauses are not entirely impossible with adjectival passives. While these data might not convince everyone that there must be an implicit argument in adjectival passives, it is at least compatible with this idea. However, we also see that purpose clauses are much more restricted with adjectival than with verbal passives, and we will come back to this point in Sections 4 and 5.

Let us then turn to the disjoint reference effect. One main argument for the proposal that verbal and adjectival passives differ in the presence/absence of Voice is the apparent lack of the 'disjoint reference effect', i.e. the availability of a reflexive reading in the latter, which was illustrated in (3) (Kratzer 1994, Rapp 1996). A further example is the following, from Roßdeutscher \& Kamp (2010).

(39) a. Die Gäste sind angemeldet. the guests are registered

(i) Someone else registered the guests.

(ii) The guests registered themselves.

b. Die Gäste wurden angemeldet.

The guests were registered

(i) Someone else registered the guests.

(ii) *The guests registered themselves. (adjectival passive)

DISJOINT INTERPRETATION

REFLEXIVE INTERPRETATION

(verbal passive)

DISJOINT INTERPRETATION

REFLEXIVE INTERPRETATION

However, as also noted by McIntyre (2013) and Bruening (to appear), this does, by far, not hold for all adjectival participles. The effect is typically illustrated with two verbs, 'comb', as in (3), and, for German additionally with anmelden 'register' in (39). Crucially, however, these two verbs are naturally reflexive, i.e. although these verbs have a transitive, disjoint construal (someone combs someone else), these verbs tend to be used reflexively (cf. Kemmer (1993) who subsumes, for example, body dress verbs like dress and grooming verbs like comb or wash among the class of naturally reflexive verbs).

Under the assumption that adjectival participles allow a reflexive interpretation because they lack a Voice projection whose implicit external argument would trigger a disjoint reference effect with the internal argument, we would predict this effect to occur with all kinds of transitive verbs. However, this is not what we find, as can be seen with e.g. töten 'kill' in (40); in fact the adjectival participles of the majority of transitive verbs do reject a reflexive interpretation.

(40) Der Einbrecher war getötet.

the burglar was killed

'The burglar was killed.'

(i) Someone killed the burglar.

(ii) *The burglar committed suicide.

As we can see in this example, the disjoint reference effect occurs also in the adjectival passive. Of course, one could propose that conceptual knowledge about killing events (they are naturally disjoint, not naturally reflexive) makes a reflexive interpretation in the absence of reflexive morphology deviant; but then disjoint reference effects become vacuous as a test. (41) from McIntyre (2013) makes the same point for English; the examples show that even a 
context explicitly supporting a reflexive interpretation cannot make a reflexive interpretation available, suggesting that the disjoint reference effect is syntactically hard wired. ${ }^{13}$

(41) a. \#John criticised himself, but to me he seemed unfairly criticised.

b. \#Some people trust themselves while others underrate themselves and think they won't succeed. Mary seems very underrated and not very trusted.

c. \#He had self-hate problems and remained very hated until he sought help.

Hence, disjoint reference effects suggest the presence of an implicit argument in adjectival passives rather than its absence. Why some adjectival passives lack the disjoint reference effect, then, is a separate issue: either there is a covert way to express reflexivity with these particular verbs or these verbs can in fact lack Voice.

In sum, unlike commonly assumed, adjectival passives do give positive results for the standard tests that have been taken to diagnose the presence of Voice. However, quantitatively, adjectival passives in English and German behave still very different from verbal passives. They pass these tests only sometimes, and we assume that the particular restrictions we find with adjectival passives follow from the fact that we are not dealing with an event particular with actual event participants, but with an event kind, which only allows event kind modification. In the following section, we will spell out the proposal of the different kinds of data sets we have discussed in Sections 2 and 3.

\section{The proposal}

We saw in Section 2 that Embick's (2004) stative participles, i.e. participles derived directly from the root, such as those in (42), cannot be equated with Kratzer's (2000) target state participles, diagnosed by the compatibility with immer noch 'still'. In particular, we have seen that some participles containing verbalizing morphology and thus behaving like Embick's resultative participles, are compatible with immer noch and thus behave like Kratzer's target state participles. Under the assumption that verbalizing morphology are instances of $\mathrm{v}$, we conclude from this that such participles can contain vPs, as in (43) (see Alexiadou \& Anagnostopoulou 2008). ${ }^{14}$

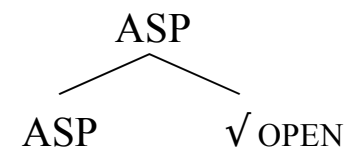

\footnotetext{
${ }^{13}$ The symbol \# indicates that only irrelevant disjoint interpretations are possible, e.g. that others criticized John in (41a).

${ }^{14}$ In the remainder of this section, we implicitly follow Embick's (2004) line of reasoning to distinguish between structurally different kinds of adjectival participles, based on the observations we made in previous sections, but we will not make more explicit our assumptions about the precise nature of Kratzer's (2000) distinction (see Gehrke 2012 and Irmer \& Mueller-Reichau 2012 for some criticism of Kratzer's still-test, Rapp 1997, Maienborn 2007a, and Gehrke to appear for different alternative pragmatic takes on the distinction between target state and resultant state participles, and Alexiadou et al. to appear for a precise syntactic implementation of Kratzer's distinction). We will, however, get back to Kratzer's (2000) proposal for resultant state participles when we discuss the Greek data in Section 5.
} 
(43)

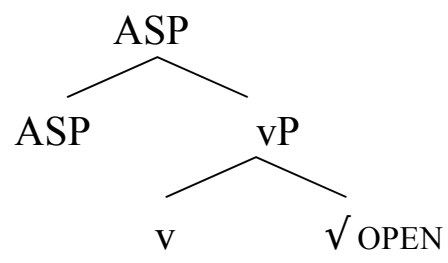

If Gese et al. (2011) and McIntyre (2013) are correct (but see Gehrke to appear), and adjectival passives of unaccusatives exist, the latter could also be the structure of adjectival participles of unaccusatives. (Furthermore, it could perhaps be the structure of the naturally reflexive predicates, which do not display the disjoint reference effect, as alluded to in the discussion of examples (39)-(41).)

Let us then turn to the question whether or not adjectival participles can contain a Voice projection. We saw that the standard tests diagnosing external arguments sometimes suggest the presence of an implicit external argument in adjectival passives. The disjoint reference effect suggests its presence almost all the time; verbal morphology is almost always compatible with an external argument being present and sometimes also strongly suggests this. In the following, we discuss different theoretical options that are compatible with these facts.

The first approach is to follow the standard assumption that Voice is always absent in adjectival passives. We think that we identified a number of arguments against this standard account. To start with, it always had the problem to explain why transitive verbs should be able to leave out Voice in the adjectival passive but not in the verbal passive or in the active. In the absence of any explanation of this, this account weakens the overall theory of argument structure. Furthermore, we have seen that transitivizing morphology sometimes explicitly suggests that adjectival participles contain a Voice projection. ${ }^{15}$ In addition, we have seen that event-related modifiers in general, including by-phrases, are sometimes possible with adjectival participles in German and English. If these participles lack Voice, we would need a theory when and how an alternative mechanism can introduce $b y$-phrases. Note in this context however that the $b y$-phrases that are acceptable with adjectival participles are a proper subset of the $b y$-phrases found in verbal participles, and this fact follows straightforwardly from an account which assumes Voice to be present, whereas the Voice-less account would have to come up with an additional explanation for it. Finally, the fact that the majority of adjectival participles displays the disjoint reference effect suggests that this account is simply wrong.

A second approach would be to assume an ambiguity, in that some adjectival participles involve Voice, whereas others do not. However, transitivizing morphology and disjoint reference effects suggest that this cannot be right, either. In particular, we find transitivizing morphology even if other tests seem to give a negative result (e.g. if the by-phrase is out). Hence, we would need a theory to predict when Voice is present and when not (see the first point above).

\footnotetext{
${ }^{15}$ It should be noted that generic middles can also contain transitivizing morphology (cf. (i)), although they seem to lack an implicit external argument. Schäfer (2008) argues that the reflexive morphology in German middles acts as an expletive external argument in the specifier of an expletive Voice projection; it is the presence of this expletive Voice projection, which triggers transitivizing morphology in middles.

(i) Das Schiff versenkt sich leicht.

the ship sinks TRANS $_{\text {REFL easily }}$

'The ship sinks easily.'

Another instance where we find transitivizing morphology in the absence of an overt subject are so called 'Fate Accusatives' in Icelandic (e.g. Maling \& Zaenen 1990). As argued by Haider (2001) and Schäfer (2008, 2012), these involve a weather pronoun in subject position, i.e. they are in fact syntactically transitive.
} 
Finally, a third option (similar to McIntyre 2013 and Bruening to appear) is to assume that Voice is present in adjectival participles derived from transitive verbs. The task of this approach, then, is to explain the restrictions we find with adjectival passives as opposed to verbal passives (i.e. the limited availability of $b y$-phrases and event-related modifiers, the limited possibility of Control into purpose clauses, and the absence at times of the disjoint reference effect) by other means, for example by postulating a specific Voice head in adjectival participles (which would be along the lines of McIntyre or Bruening) or by proposing a semantic (in particular sortal) difference between the events involved in verbal and in adjectival passives, as proposed in Gehrke (2011, and subsequent work). In particular, we need a theory to predict when Voice can license overt $b y$-phrases (etc.) and when not. We think the third hypothesis is the most promising.

Following Bruening (to appear), then, we assume an extra position on top of Voice, PASS, which produces verbal and adjectival passives (as well as nominalizations), as illustrated in (44) and (45) (cf. Anagnostopoulou 2003, Alexiadou \& Anagnostopoulou 2008).
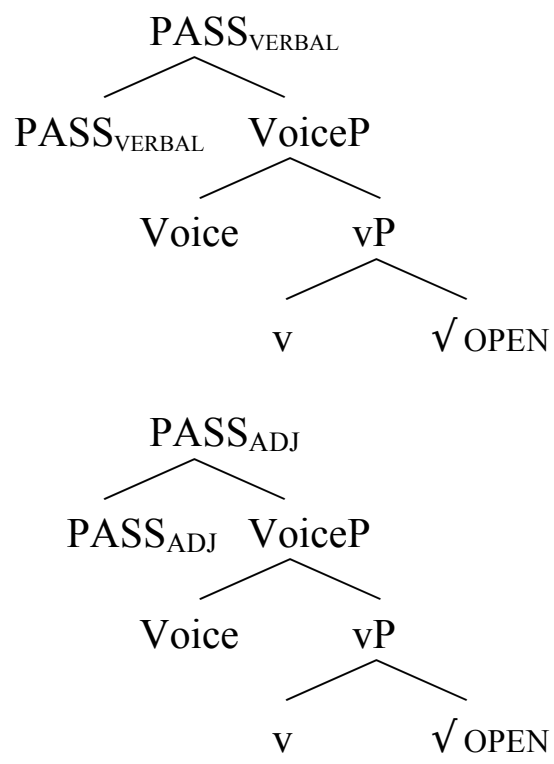

Following Alexiadou et al. (2012), we assume that these heads introduce a Voice-shifting projection. Both PASS-heads select for VoicePs without specifier (see Bruening to appear for a possible way of implementation). PASS ${ }_{\text {VERBAL }}$ does not shift the category and the event properties, and it basically absorbs the external argument. PASS $\mathrm{ADJ}_{\mathrm{A}}$ shifts, in addition, the category and stativizes the event (derived stative).

A question that arises under this account is how to derive the restrictions on $b y$-phrases and other modifiers as well as Control that we still find in adjectival passives, which is a problem for Bruening (to appear). We would like to relate this to the stative semantics of adjectival passives, and propose that these restrictions are not (argument) structural or syntactic in nature, but rather semantic. We follow Gehrke (2011, and subsequent work), who proposes that an adjectival passive construction refers to the instantiation of a consequent state kind of an event kind. ${ }^{16}$ For example, the semantics she proposes for (46a) is given in (46b) (ignoring the contribution of Tense), where the subscripts ${ }_{0}$ and $\mathrm{k}_{\mathrm{k}}$ respectively specify whether the entity in question (including states $\mathrm{s}$ and events e) refers to a token or a kind.

\footnotetext{
${ }^{16}$ Consequent state here is used as a cover term for result states (with accomplishments and achievements) as well as inchoative states (with states; recall fn. 9); hence the term event here should be understood in a broader, Neo-Davidsonian way to also include states. See Gehrke (to appear) for further discussion and also for a motivation to use BECOME in the formula in (46).
} 
(46) a. Die Tür ist geschlossen.

the door is closed

'The door is closed.'

b. $\exists \mathrm{s}_{0}, \mathrm{e}_{\mathrm{k}}, \mathrm{x}_{\mathrm{k}}\left[\operatorname{close}\left(\mathrm{e}_{\mathrm{k}}\right) \wedge \operatorname{BECOME}\left(\mathrm{s}_{0}\right)\left(\mathrm{e}_{\mathrm{k}}\right) \wedge \operatorname{closed}\left(\right.\right.$ the door, $\left.\left.\mathrm{s}_{0}\right) \wedge \operatorname{INITIATOR}\left(\mathrm{x}_{\mathrm{k}}, \mathrm{e}_{\mathrm{k}}\right)\right]$

In the following, we will shortly spell out the underlying assumptions of this account; for more details the interested reader is referred to the works cited, as well as to Gehrke \& Sánchez Marco (this volume).

Gehrke extends the notion of kinds, introduced for the nominal domain by Carlson (1977), to the verbal domain. For the nominal domain, Zamparelli (1995) has argued that nominal predicates start out as predicates of kinds and get instantiated (or realized) to enable reference to an entity token when embedded under Num(ber). In analogy, Gehrke (to appear) proposes that verbal predicates enter the derivation as predicates of event kinds; the event gets instantiated only when such verbal structure is embedded under further functional structure, such as Tense/Aspect, to refer to an event token, i.e. an event that has taken, is taking, or is going to take place in the actual world. Given that in adjectival passives, verbal predicates are not directly embedded under Tense/Aspect but instead under an adjectivising head (AP in her proposal; PASS ${ }_{\text {adj }}$ here), it is argued that as a result of this category change, the underlying event associated with the verb does not get instantiated but remains in the kind domain. The consequent (i.e. result or inchoative) state associated with the verbal predicate, in turn, is embedded under Tense/Aspect and thus (can) get instantiated at some later stage, in analogy to states associated with adjectives more generally.

Restrictions on event-related modification, then, are argued to follow from general restrictions on kind modification. For example, given that kinds are not instantiated they lack spatio-temporal location; from this it follows that the event cannot be modified by spatial or temporal modifiers, as evidenced, for instance, by $(30 \mathrm{~b}, \mathrm{c})$. NPs naming participants in the event, in turn, such as those in by-phrases or instruments, cannot name actual event participants of an event particular, given that there is no event particular (no event token) to begin with. Gehrke (to appear) proposes that PPs introducing event participants, such as byand with-phrases, have to pseudo-incorporate into the participle before adjectivization can take place. This proposal is motivated by the fact that the nominals in such PPs behave like weakly or non-referential nominals and display semantic properties of (pseudo-)incorporated nominals (e.g. Dayal 2011, and references cited therein). In particular, pseudo-incorporated nouns obligatorily take narrow scope with respect to quantificational elements in the clause, do not introduce discourse referents (e.g. they do not support pronominal anaphora), and cannot be modified by (ordinary restrictive token) modifiers. All these properties also hold for the nominals in event-related modifiers of adjectival passives, as shown in (47a-c).

a. Alle Briefe waren mit (einem) $\begin{aligned} & \text { Bleistift geschrieben. } \\ & \text { all letters were with a }\end{aligned}$ pencil written

$=$ 'All letters were written with a pencil.' (possibly more than one pencil)

$\neq$ 'There was a particular pencil that all letters were written with.'

OBLIGATORY NARROW SCOPE

b. Die Zeichnung ist/war von [einem Kind $]_{i}$ angefertigt. ${ }^{*} E s_{i}$ hatte rote Haare. the drawing is was by a child produced it had red hairs intended: 'The drawing is/was produced by [a child] $]_{i}$ (S)he i $_{i}$ had red hair.'

NO DISCOURSE REFERENT

c. *Die Zeichnung ist/war von einem blonden Kind angefertigt. the drawing is was by a blond child produced 
intended: 'The drawing is/was produced by a blond child.'

NO TOKEN MODIFICATION
d. ??Der Brief ist mit diesem Bleistift geschrieben. the letter is with this pencil written intended: 'The letter is written with this pencil.'

NO STRONGLY REFERENTIAL NOUN PHRASES

This account is further supported by the higher propensity for weakly or non-referential noun phrases in such PPs, such as indefinite and bare nominals, as opposed to fully referential ones, such as (strong) definite nominals, evidenced by the oddness of, e.g., (47d); recall also (23) (see Gehrke \& Sánchez Marco, this volume, for similar data from Spanish). ${ }^{17}$

An additional constraint is suggested by McIntyre (to appear), building on insights from Rapp (1997) and Meltzer-Asscher (2011):

(48) State Relevance Hypothesis In adjectival passives in e.g. German, English, Hebrew, event-related satellites are unacceptable unless they contribute to the description of the state expressed by the participle or of the theme during the interval $i$ during which this state holds. They are most acceptable if they provide information which can be inferred solely by inspection of the theme during interval $i$.

Note, however, that the State Relevance Hypothesis still maintains that the modifiers in question modify an event and not the state directly (unlike what Meltzer-Asscher proposes).

All in all, then, there is ample motivation for positing semantic constraints on event-related modification of adjectival participles, which are nevertheless still compatible with a Voice layer in the syntactic structure of such participles. Our overall proposal predicts that the examples in which by-phrases are acceptable are similar/reproducible across languages. Furthermore, contextual factors that have been shown to improve by-phrases (on which see, e.g., Rapp 1997, Maienborn 2007a, Gehrke to appear) should be identical across languages. At least the facts from English and German point into this direction, and Spanish seems to pattern with these languages as well (see Gehrke \& Sánchez Marco, this volume). However, this does not explain why Greek seems to be so much more productive, and we will turn to a possible explanation of this fact in the final section of this paper.

\section{Cross-linguistic variation}

In this last section, we will address the question of why Greek differs from English and German both as far as the distribution of by-phrases is concerned, and the type of modifiers allowed with adjectival participles. An answer to this question is provided in Alexiadou et al. (to appear), and we summarize here their observations and their account.

Alexiadou et al. (to appear) argue that in order to understand similarities and differences in the properties of Voice in different kinds of participles within and across languages, it is important to take a closer look at Kratzer's (2000) account of the target- vs. resultant-state distinction. They propose that the differences between Greek, on the one hand, and German and English, on the other, can be accounted for by appealing to the type vs. token distinction. In Greek, stativization involves (or rather can involve) a Perfect operator leading to the interpretation that the run time of the verbal event took place before the time denoted by the

\footnotetext{
${ }^{17}$ The idea that the underlying event in adjectival passives remains in the kind domain has been taken up by Gese (2011) who provides additional experimental evidence that we are dealing with event kinds rather than event particulars; see also Maienborn \& Geldermann (2013) for further considerations within an event kind approach to adjectival passives.
} 
stativized vP or VoiceP, following Kratzer's (2000: 12) proposed semantics for the stativizer deriving resultant state participles, given in (49); the tree we propose for this case is given in (50), in the spirit of Alexiadou et al. (to appear).

(49) $\lambda \mathbf{P} \lambda t \exists e[\mathbf{P}(e) \& \tau(e)<t]$

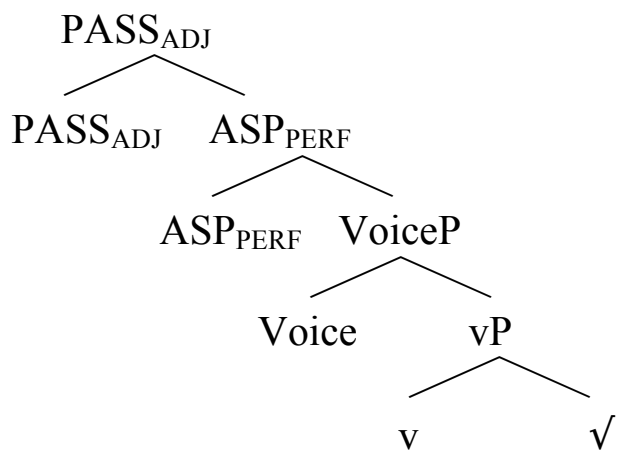

Due to the presence of this aspectual operator, then, the event gets instantiated (it has a run time) and we are dealing with an event token. In German and English, on the other hand, there is no Perfect operator in adjectival participles in general (contra Kratzer 2000), but stativization existentially binds the event variable introduced by $\mathrm{v}$; this leads to an event kind interpretation, as suggested in the previous section.

In contrast, Alexiadou et al. (to appear) pursue an analysis of Greek target state participles, according to which these can only be built when a stativizer attaches immediately above the $\mathrm{vP}$, i.e. these have a structural representation along the lines of (43). To account for the availability of $b y$-phrases, instrumental and manner modifiers within target state participles, Alexiadou et al. propose that the stativized $\mathrm{vP}$ expressing the target state resulting from the event it relates to can only combine with a Voice head introducing the theta-role of holder, (51), exactly as proposed in Kratzer (1996).

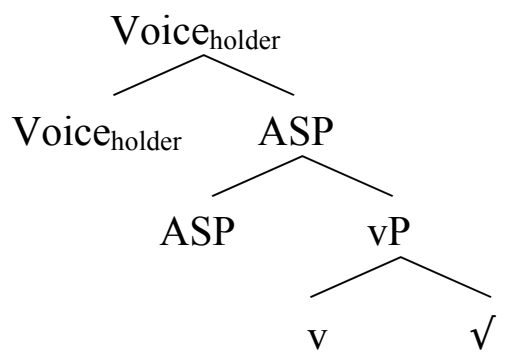

As a result, the implicit external argument is an argument of a stativized/adjectivized verbal construction, and Voice-related material must be directly modifying the target state, since it relates to the holder of that state. For example, Greek is quite liberal with respect to Voice modifiers in resultant state participles, but not in target state participles. Consider (52), from Alexiadou et al. (to appear). The presence of still enforces a target state participle, and byphrases and instruments are licit only when the referents of the $b y$-phrase or instrument are present in the state as in $(52 \mathrm{~b}, \mathrm{c})$ :

(52) a. Ta lastixa ine (*akoma) fuskomena apo tin Maria.

The tires are (still) inflated by the Mary

'The tires are still inflated by Mary.'

b. To stadio ine akomi perikiklomeno apo tin astinomia. 
The stadium is still surrounded by the police

'The stadium is still surrounded by the police.'

c. O skilos ine akomi demenos me skini.
The dog is still tied
'The dog is still tied with a leash.'

'The dog is still tied with a leash.'

Even though nominals introduced by by or with as in $(52 \mathrm{~b}, \mathrm{c})$ are commonly participants in an event (initiators or instruments) and such PPs should thus be modifying the event directly and not the state (as we argued in the previous sections for German and English), at the same time they also participate in and exist during the state. Hence, they exist during the interval associated with the state, which is in accordance with McIntyre's (to appear) State Relevance Hypothesis given in (48). This also makes sense intuitively: During the state in question, the police are located around the stadium (52b), and the leash is around the dog (52c). We leave open whether this account can or should be extended to other languages. ${ }^{18}$

The final question that arises then is to which extent Greek resultant state participles are different from the Perfect of eventive passives built on the basis of HAVE + uninflected passive participle, as both constructions contain Voice. Alexiadou \& Anagnostopoulou (2008) argue that the $\mathrm{BE}+$ uninflected participle in -menos construction has the semantics of the Perfect of Result, cf. Veloudis (1990), and Kordoni (2002). If there is indeed a difference between the two, this would have to relate to the fact that an experiential reading is possible only for the HAVE + uninflected participle construal, and not for the BE + -menos participle construal.

(51) a. To vivlio ehi diavasti.

the book has read-NAct

'The book has been read.'

b. To vivlio ine diavasmeno.

the book is read-neut

'The book is read/has been read.'

In order to test the difference between the two constructions, we need to examine their behaviour in contexts that trigger an experiential reading only, i.e. the result state can be denied. In Greek such contexts are found in the presence of e.g. the adverbial mehri tora 'until now', which is an adverb that triggers an experiential perfect reading (cf. Giannakidou 2003). In such a context (52a) is fine, while (52b) sounds odd.
a. To thema ehi diavasti 74 fores.
the issue has read-NACT 74 times
'The issue has been read 74 times.'
b. \#To thema ine diavasmeno 55 fores.
the issue is read-neut 55 times
'The issue is read 55 times.'

This would seem to suggest that while the HAVE + passive participle construction is ambiguous between a perfect of result and an experiential reading, the BE+ -menos participle

\footnotetext{
${ }^{18}$ Alexiadou et al. (to appear) extend this analysis to other languages, whereas Gehrke (2013), following Rapp (1996), argues that a structure like that in (51), in which the modifiers target the state directly (after adjectivization), is only available for participles derived from stative verbs (or roots), whereas those that are derived from eventive verbs (roots) combine with event-related modifiers before adjectivization (and involve pseudo-incorporation, as outlined in section 4; Gehrke to appear).
} 
construction allows only the resultative interpretation. Crucially, however, the difference between the two would relate to the type of ASP operator included, and would not be due to the presence vs. absence of Voice (von Stechow 2002). This operator, unlike PASS does not absorb an external argument. Further research is necessary in order to determine further differences between the two constructions. We will leave this topic for future research. ${ }^{19}$

\section{Conclusion}

In this paper, we provided empirical evidence for the claim that adjectival participles in German, English can contain verbal layers, in particular v (as already proposed by Embick 2004), but also, contra the common assumption, Voice (as recently argued by McIntyre and Bruening to appear). In this respect, German and English participles do not radically differ from their Greek counterparts. We provided further support for the view that adjectival participles can come in different sizes, whether they are derived from roots (Embick's stative participles), verbalized roots containing $\mathrm{v}$ (Embick's resultative participles), or those containing a further Voice layer, which then constitutes a third type of adjectival participle, as already proposed in Anagnostopoulou (2003) and Alexiadou \& Anagnostopoulou (2008) for Greek.

However, there are differences between English and German, on the one hand, and Greek, on the other, which had already been noted in the literature: the availability of event-related modification, such as manner adverbs, by- and with-phrases, with adjectival participles in English and German is much more restricted than in Greek. We proposed, following Alexiadou et al. (to appear), that this difference does not force an account in terms of the absence vs. presence of Voice, but instead resorted to a semantic explanation. In particular, we suggested, following Gehrke (2011, and subsequent work) that due to the fact that adjectival participles are not embedded under further functional verbal structures like Aspect and Tense, but adjectivized instead, the event associated with this participle remains in the kind domain and does not get instantiated. From this it follows that event-related modification is restricted to kind modification. For Greek, in turn, we suggested that adjectival participles (can) contain an additional Perfect operator, which leads to the event associated with the participle embedded under Aspect to get instantiated. Finally, we showed that such adjectival passive constructions in Greek still differ from perfect constructions.

One point that arose from the empirical generalization was that Embick's (2004) distinction between stative and resultative participles, analyzed in terms of the absence vs. presence of v, cannot be equated with Kratzer's (2000) distinction between target state and resultant state participles, as diagnosed by the (in)compatibility with still. In particular, we found adjectival participles containing verbalizing morphology (i.e. Embick's resultative participles) that were still compatible with still (which is supposed to show that we are dealing with a target state participle). Whether or not Kratzer's distinction should be reflected in a structural distinction, as suggested by Alexiadou et al. (to appear), also from a crosslinguistic perspective, and not just for Greek, remains to be investigated.

\footnotetext{
${ }^{19}$ We note briefly, however, that participial constructions have been re-analyzed many times in the history of Greek. For instance, the string $\mathrm{BE}+$ participle in -menos was the only way to form the perfect for many centuries in the history of Greek, dating from 4th century BC to nearly 19th century AD (cf. Alexiadou to appear for discussion). Although historically, the $\mathrm{BE}+$ participle started off as a resultative construction, it grammaticalized into a perfect around the 5th century BC. The Modern Greek perfect emerged during the Medieval Greek period out of an earlier 'have' future/conditional tense (basically have + aorist infinitive). This form grammaticalized as a perfect towards the 19th century.
} 


\section{Acknowledgments}

We are grateful to two anonymous reviewers and the participants to the Workshop on Aspect and Argument Structure of Adjectives and Participles in London in June 2012, and the Workshop on Conversion and Mixed Categories in Porto in November 2012 for their comments and suggestions. Many thanks to Elena Anagnostopoulou for clarifying a number of issues with us and to Jim Wood for discussing Icelandic data with us. Alexiadou and Schäfer's research was supported by a DFG grant to project B6 Underspecification in Voice systems and the syntax-morphology interface as part of the Collaborative Research Center 732 Incremental Specification in Context at the University of Stuttgart. Gehrke's research was supported by a MICINN grant to the project JCI-2010-08581, as well as a MINECO grant to the project FFI2010-15006.

\section{References}

Alexiadou, Artemis (to appear). On the irrealis effect on auxiliay selection. In R. Kailuweit \& M. Rosemeyer (eds.), Auxiliary Selection: Gradience and Gradualness. Linguae \& Litterae. Berlin: Mouton de Gruyter.

Alexiadou, Artemis \& Elena Anagnostopoulou (2008). Structuring participles. In C.B. Chang \& H.J. Haynie (eds.), Proceedings of WCCFL 26. Cascadilla Proceedings Project Somerville, MA, 33-41.

Alexiadou, Artemis, Elena Anagnostopoulou \& Florian Schäfer (2006). The properties of anticausatives crosslinguistically. In M. Frascarelli (ed.), Phases of Interpretation. Berlin: Mouton de Gruyter, 187-212.

Alexiadou, Artemis, Elena Anagnostopoulou \& Florian Schäfer (to appear). External Arguments in Transitivity Alternations: A Layering Approach. Oxford: Oxford University Press.

Alexiadou, Artemis, María Ángeles Cano, Gianina Iordachioaia, Fabienne Martin \& Florian Schäfer (2012). 'Direct participation' and 'agent exclusivity' effects in derived nominals and beyond. In G. Iordachioaia, I. Roy \& K. Takamine (eds.), Categorization and Category Change in Morphology. Newcastle upon Tyne: Cambridge Scholars Publishing, 155-182.

Anagnostopoulou, Elena (2003). Participles and Voice. In A. Alexiadou, M. Rathert \& A. von Stechow (eds), Perfect Explorations. Berlin: de Gruyter, 1-36.

Anagnostopoulou, Elena \& Yota Samioti (to appear). Domains within words and their meanings: A case study. In A. Alexiadou, H. Borer \& F. Schäfer (eds.), The Syntax of Roots and the Roots of Syntax. Oxford: Oxford University Press.

Baker, Mark, Kyle Johnson, \& Ian Roberts (1989). Passive argument raised. Linguistic Inquiry 20:219-251.

Bhatt, Rajesh \& Roumyana Pancheva (2006). Implicit Arguments. In M. Everaert \& H. van Riemsdjik (eds.), The Blackwell Companion to Syntax. Oxford: Blackwell, 554-584.

Bruening, Benjamin (to appear). Word formation is syntactic: Adjectival passives in English. To appear in Natural Language and Linguistic Theory.

Carlson, Gregory N. (1977). Reference to Kinds in English. Ph.D. dissertation, University of Massachusetts at Amherst.

Dayal, Veneeta (2011). Hindi pseudo-incorporation. Natural Language and Linguistic Theory 29.1:123-167.

Doron, Edit (to appear). The interaction of adjectival passive and voice. In A. Alexiadou, H. Borer \& F. Schäfer (eds.), The Syntax of Roots and the Roots of Syntax. Oxford: Oxford University Press.

Embick, David (2004). On the structure of resultative participles in English. Linguistic Inquiry 35.3:355-392. 
Embick, David (2010). Localism versus Globalism in Morphology and Phonology. Cambridge, MA: MIT Press.

Emonds, Joseph (2006). Adjectival passives. In M. Everaert \& H. van Riemsdijk (eds.), The Blackwell Companion to Syntax. Oxford: Blackwell, 16-60.

Gehrke, Berit (2011). Stative passives and event kinds. In I. Reich, E. Horch \& D. Pauly (eds.), Proceedings of Sinn und Bedeutung 15. Saarbrücken: Universaar - Saarland University Press, 241-257.

Gehrke, Berit (2012). Passive states. In V. Demonte \& L. McNally (eds.), Telicity, Change, and State: A Cross-Categorial View of Event Structure. Oxford: Oxford University Press, 185-211.

Gehrke, Berit (2013). Puzzled by adjectival passives. In R. Folli, C. Sevdali \& R. Truswell (eds.), Syntax and its Limits. Oxford: Oxford University Press, 175-191.

Gehrke, Berit (to appear). Adjectival participles, event kind modification and pseudoincorporation. To appear in Natural Language and Linguistic Theory.

Gehrke, Berit \& Cristina Sánchez-Marco (this volume). The role of by-phrases in adjectival passives. To appear in Lingua.

Gese, Helga (2011). Events in adjectival passives. In I. Reich, E. Horch \& D. Pauly (eds.), Proceedings of Sinn und Bedeutung 15. Saarbrücken: Universaar - Saarland University Press, 259-273.

Gese, Helga, Claudia Maienborn \& Britta Stolterfoht (2011). Adjectival conversion of unaccusatives in German. Journal of Germanic Linguistics 23.2:101-140.

Giannakidou, Anastasia (2003). A puzzle about until and the Present Perfect. In A. Alexiadou, M. Rathert, \& A. von Stechow (eds.), Perfect Explorations. Berlin: de Gruyter, 101-133.

Haider, Hubert (2001). How to stay accusative in insular Germanic. Working Papers in Scandinavian Syntax 68:1-14.

Harley, Heidi (2011). An alternative to deficiency approaches to the manner-alternation parameter. Paper presented at the Workshop on Verbal Elasticity, Universitat Autònoma de Barcelona, October 2011.

Irmer, Matthias \& Olav Mueller-Reichau (2012). Conditions for the exclusion of immer noch in German adjectival passives. Paper presented at Concept Types and Frames in Language, Cognition, and Science (CTF'12), University of Düsseldorf, August 2012.

Kemmer, Suzanne (1993). The Middle Voice. Amsterdam: John Benjamins.

Kordoni, Valia (2002). Participle-adjective formation in Modern Greek. In M. Butt \& T. Holloway King (eds.), Proceedings of the LFG02 Conference, National Technical University of Athens. Stanford, CA: CSLI Publications, 220-238.

Kratzer, Angelika (1994). The Event Argument and the Semantics of Voice. Chapter 2: Adjectival Passives. Ms. Amherst.

Kratzer, Angelika (1996). Severing the external argument from its verb. In J. Rooryck \& L. Zaring (eds.), Phrase Structure and the Lexicon. Dordrecht: Kluwer, 109-137.

Kratzer, Angelika (2000). Building statives. In L. Conathan, J. Good, D. Kavistkaya, A. Wulf \& A. Yu (eds.), Proceedings of the Berkeley Linguistic Society 26, 385-399.

Kratzer, Angelika (2005). Building resultatives. In C. Maienborn \& A. Wöllstein (eds.), Event Arguments: Foundations and Applications. Tübingen: Niemeyer, 177-212.

Lazckó, Tibor (2001). Another look at participles and adjectives in the English DP. In M. Butt and T. Holloway King (eds.), Proceedings of the LFG01 Conference, University of Hong Kong, Hong Kong. Stanford, CA: CSLI Publications, 201-220.

Levin, Beth \& Malka Rappaport (1986). The formation of adjectival passives. Linguistic Inquiry 17, 623-661. 
Lundquist, Björn (2008). Nominalizations and Participles in Swedish. Ph.D. dissertation, University of Tromsø.

Maienborn, Claudia (2007a). Das Zustandspassiv: Grammatische Einordnung Bildungsbeschränkung - Interpretationsspielraum. Zeitschrift für germanistische Linguistik 35:83-144.

Maienborn, Claudia (2007b). On Davidsonian and Kimian states. In I. Comorovski \& K. von Heusinger (eds.), Existence: Semantics and Syntax. Dordrecht: Springer, 107-130.

Maienborn, Claudia (2011). Strukturausbau am Rande der Wörter: Adverbiale Modifikatoren beim Zustandspassiv. In S. Engelberg, A. Holler \& K. Proost (eds.), Sprachliches Wissen zwischen Lexikon und Grammatik. Berlin: Mouton de Gruyter, 317-343.

Maienborn, Claudia \& Sascha Geldermann (2013). 'Expertengeprüft' und 'vom Experten geprüft': Zur Semantik von Nomen-Partizip II-Komposita und ihrer präpositionalen Partner. In H. Härtl (ed.), Interfaces of Morphology: A Festschrift for Susan Olsen. Berlin: Akademie Verlag, 127-162.

Maling, Joan \& Annie Zaenen (1990). Unaccusative, passive, and quirky case. In J. Maling \& A. Zaenen (eds.), Modern Icelandic Syntax. New York: Academic Press, 137-152.

Martin, Fabienne \& Florian Schäfer (to appear). Causation at the Syntax-Semantics Interface. In B. Copley \& F. Martin (eds.), Causation in Grammatical Structures. Cambridge University Press.

McIntyre, Andrew (2013). Adjectival passives and adjectival participles in English. In A. Alexiadou \& F. Schäfer (eds.), Non-canonical Passives. Amsterdam: John Benjamins.

McIntyre, Andrew (to appear). Event modifiers in (German) adjectival passives: Remarks on Gehrke (this issue). To appear in Natural Language and Linguistic Theory.

Meltzer-Asscher, Aya (2011). Adjectival passives in Hebrew: Evidence for parallelism between the adjectival and verbal systems. Natural Language and Linguistic Theory 29:815-855.

Parsons, Terence (1990). Events in the Semantics of English: A Study in Subatomic Semantics. Cambridge, MA: MIT Press.

Pylkkänen, Liina (2008). Introducing Arguments. Cambridge, MA: MIT Press.

Rapp, Irene (1996). Zustand? Passiv? Überlegungen zum sogenannten "Zustandspassiv". Zeitschrift für Sprachwissenschaft 15.2:231-265.

Rapp, Irene (1997). Partizipien und semantische Struktur: Zu passivischen Konstruktionen mit dem 3. Status. Tübingen: Stauffenburg.

Roßdeutscher, Antje \& Hans Kamp (2010). Syntactic and semantic constraints in the formation and interpretation of ung-nouns. In A. Alexiadou \& M. Rathert (eds.), The Semantics of Nominalisations across Languages and Frameworks. Interface Explorations 22, Berlin: Mouton de Gruyter, 169-214.

Samioti, Yota (to appear). Issues in the Lexicon-Syntax Interface and Applications in Modern Greek as a $2^{\text {nd }}$ Language: The case of participles. Ph.D. dissertation, University of Crete.

Schäfer, Florian (2008). The Syntax of (Anti-)Causatives. External arguments in change-of state contexts. Amsterdam: John Benjamins.

Schäfer, Florian (2012). The passive of reflexive verbs and its implications for theories of binding and case. Journal of Comparative Germanic Linguistics 15.3:213-268.

Schlücker, Barbara (2005). Event-related modifiers in German adjectival passives. In E. Maier, C. Bary \& J. Huitink (eds.), Proceedings of Sinn und Bedeutung 9. Radboud University Nijmegen, 417-430.

Sleeman, Petra (2011). Verbal and adjectival participles: internal structure and position. Lingua 121:1569-1587.

Sigurðsson, Halldór A. (1989). Verbal Syntax and Case in Icelandic. Doctoral dissertation, University of Lund. 
Veloudis, Ioannis (1990). The meta-linguistic character of the Perfect: the Present Perfect. Studies in Greek Linguistics 13: 359-378.

von Stechow, Arnim (1996). The different readings of wieder 'again': A structural account. Journal of Semantics 13:87-138.

von Stechow, Arnim (1998). German participles II in Distributed Morphology. Ms. University of Tübingen.

von Stechow, Arnim (2002). German seit 'since' and the ambiguity of the German perfect. In B. Stiebels \& I. Kaufmann (eds.), More than Words: A Festschrift for Dieter Wunderlich. Berlin: Akademie-Verlag, 393-432.

Wasow, Thomas (1977). Transformations and the lexicon. In P. Culicover, T. Wasow \& J. Bresnan (eds.), Formal Syntax. New York: Academic Press, 327-360.

Williams, Edwin (1985). PRO and the subject of NP. Natural Language and Linguistic Theory 3:297-315.

Zamparelli, Roberto (1995). Layers in the Determiner Phrase. Ph.D. dissertation, University of Rochester. 